\title{
A study of new varieties of spring wheat selected at Far Eastern State Agrarian University in crop variety nurseries
}

\author{
Larisa Mishenko ${ }^{1,{ }^{*}}$, Mikhail Terekhin ${ }^{1}$, and Nikolai Terekhin ${ }^{1}$ \\ ${ }^{1}$ Far Eastern State Agrarian University ,86, Politeknicheskaya Str., Blagoveschensk, Amur region, \\ Russia
}

\begin{abstract}
The most important provision for ensuring high, stable spring wheat yields is the cultivation of new varieties, adapted to local agricultural conditions. Amur region's specific climate and rapid development of fungal diseases during the vegetation period require particular crop varieties that are resistant to adverse factors. To create a variety that combines several targeted parameters that are stably manifested under different vegetation conditions in different years is a difficult and troublesome task since in many cases the needed features have an inverse dependence. The following paper presents the results of a threeyear study of new varieties of spring wheat from cultivation nurseries. The data of field studies on the height of plants and their resistance to lodging and diseases, the duration of vegetation season, and productivity are presented. The analysis of grain quality of new varieties of wheat from Far Eastern State Agrarian University selection for hardness, natural weight, and kernel size was conducted. Most of the studied cultivation samples are medium-sized, quite resistant to lodging, successfully withstanding significant soil excessive moistening. Against natural infection background, some varieties are resistant to such dangerous, widespread infections as dust-brand, grain fusariose, and kernel black point of grain. Varieties with yields above standard, which can be classified by the quality of grain as valuable and strong wheat were identified. As part of the analysis of obtained data on several economically valuable traits, four promising spring wheat varieties can be distinguished to recommend them for the federal variety test: KSI-6, 13, 17, 18 .
\end{abstract}

\section{Introduction}

The most important provision for ensuring high, stable spring wheat yields is the cultivation of new varieties, adapted to local agricultural conditions. Amur region's specific climate and rapid development of fungal diseases during the vegetation period require particular crop varieties that are resistant to adverse factors. The crop and its quality are influenced by many factors, the most important of them are studied in a testing nursery. To create a

\footnotetext{
${ }^{*}$ Corresponding author: laridass2@mail.ru
} 
variety that combines some targeted parameters which are stably manifested under different vegetation conditions in different years is a difficult and troublesome task since in many cases the needed features have an inverse dependence. This way, the higher is the yield, the lower is the grain quality and the more intense is disease affection.

The study of varietal samples for three to four years allows the authors to draw conclusions about the suitability of varieties for cultivation and recommend the most successful ones for the federal variety test.

\section{Research Methods and Conditions}

The crop nursery establishment was done according to the standard scheme: the square area of a testing plot was $10 \mathrm{~m}^{2}$ (square meters, metric), the repetition was 6-fold. Sowing was done with SKS-6A precision seeder at the optimum period for the southern zone (2nd - $3 \mathrm{~d}$ 10-day period of April) with the seeding rate of 5.5 million germinable grains per hectare. Harvesting was done by Sampo-130 self-propelled combine. (Procedures of the Federal Commission for Variety Testing of Agricultural Crops, 1985).

The temperature variables in 2017-2019 were relatively homotypic and their deviations from the long-term average values totaled only 1-3 degrees, while the amount of precipitation exceeded the standard rates by $1.5-2$ times in certain months (Table 1).

Table 1. Meteorological data during the $2017-2019$ vegetation periods (according to the hydrometeorological office of Blagoveschensk).

\begin{tabular}{|c|c|c|c|c|c|c|c|c|c|c|}
\hline \multirow{3}{*}{ Month } & \multicolumn{5}{|c|}{ Temperature, ${ }^{\circ} \mathrm{C}$} & \multicolumn{5}{|c|}{ Precipitation, $\mathrm{mm}$} \\
\hline & \multicolumn{3}{|c|}{$\begin{array}{c}\text { average for } \\
\text { 10-days periods }\end{array}$} & \multirow{2}{*}{$\begin{array}{l}\text { the } \\
\text { averag } \\
\text { e for } \\
\text { the } \\
\text { month }\end{array}$} & \multirow{2}{*}{ aberration } & \multicolumn{3}{|c|}{$\begin{array}{c}\text { average for } \\
10 \text {-days periods }\end{array}$} & \multirow{2}{*}{$\begin{array}{l}\text { monthly } \\
\text { precipitation }\end{array}$} & \multirow{2}{*}{$\begin{array}{l}\% \text { of } \\
\text { rate }\end{array}$} \\
\hline & 1 & 2 & 3 & & & 1 & 2 & 3 & & \\
\hline \multicolumn{11}{|c|}{2017} \\
\hline April & 5.8 & 2.2 & 7.4 & 5.1 & 1 & 7 & 15 & 36 & 58 & 181 \\
\hline May & 14.0 & 14.6 & 13.9 & 14.2 & 2 & 16 & 11 & 14 & 41 & 98 \\
\hline June & 14.9 & 19.7 & 22.4 & 19.0 & 0 & 11 & 50 & 36 & 97 & 107 \\
\hline July & 26.7 & 21.4 & 19.4 & 22.5 & 1 & 29 & 34 & 26 & 89 & 68 \\
\hline August & 20.9 & 23.9 & 14.9 & 19.9 & 1 & 78 & 4 & 39 & 121 & 97 \\
\hline \multicolumn{11}{|c|}{2018} \\
\hline April & 1.7 & 7.5 & 11.0 & 6.7 & 3 & 0 & 0 & 0 & 0 & 0 \\
\hline May & 11.3 & 15.8 & 16.1 & 14.4 & 2 & 9 & 11 & 6 & 26 & 62 \\
\hline June & 19.3 & 16.1 & 18.4 & 17.9 & -1 & 24 & 123 & 21 & 168 & 185 \\
\hline July & 21.0 & 22.8 & 23.0 & 21.5 & 1 & 42 & 34 & 83 & 159 & 121 \\
\hline August & 21.3 & 19.5 & 19.6 & 20.1 & 1 & 11 & 5 & 84 & 100 & 80 \\
\hline \multicolumn{11}{|c|}{2019} \\
\hline April & 2.8 & 5.4 & 8.4 & 5.5 & 1 & 0 & 7 & 1 & 8 & 25 \\
\hline May & 10.3 & 13.7 & 13.0 & 12.3 & 0 & 2 & 38 & 46 & 86 & 205 \\
\hline June & 18.8 & 16.5 & 19.6 & 18.1 & 1 & 4 & 53 & 20 & 77 & 85 \\
\hline July & 21.2 & 22.6 & 20.3 & 21.3 & 0 & 82 & 86 & 90 & 258 & 197 \\
\hline August & 20.3 & 18.2 & 18.2 & 18.9 & 0 & 96 & 43 & 52 & 191 & 153 \\
\hline
\end{tabular}

The largest amount of rainfall in May-August occurred in 2019, while more than half of the rain fell during the filling, ripening, and harvesting of grain, which harmed variety 
yields and the quality of grain obtained in 2019. However, such weather conditions allows to identify the features of individual breeding samples, their stability, and resistance to adverse environmental factors.

\section{Results and Discussion}

In the situation of frequent overwetting during ripening and harvesting periods, such variety feature as resistance to lodging is very important. Grains from lodged plants are more affected by fungal diseases, they increasingly accumulate humidity and tend to sprout more actively while still unharvested. They are influenced by both culm mechanical characteristics, its diameter, the capacity of mechanical tissues, and the height of plants [14]. According to European standards, varieties with stems up to $120 \mathrm{~cm}$ (centimeters, metric) are considered regular in height, those with stems up to $100 \mathrm{~cm}$ - are medium-tall, those with stems up to $80 \mathrm{~cm}$ - are short-stemmed and most resistant to lodging (3). The culm length of most varieties, studied over three years was 70-95 cm, resistance to lodging - 5-9 points (Table 2). 2019 overwetting revealed 9 varieties with good resistance to moisture, as they remained stable at the level of at least 7 points.

Table 2. Height and Lodging Resistance of Crop Plants.

\begin{tabular}{|l|c|c|c|c|c|c|}
\hline \multirow{2}{*}{ Variety } & \multicolumn{3}{c|}{ Plant height, cm. } & \multicolumn{3}{c|}{ Lodging Resistance, points } \\
\cline { 2 - 7 } & 2017 & 2018 & 2019 & 2017 & 2018 & 2019 \\
\hline 3. DalGAU 1 standard & 70 & 90 & 80 & 8 & 6 & 7 \\
\hline 6. DalGAU 1 x Turinskaya & 75 & 95 & 80 & 7 & 9 & 7 \\
\hline 7. Amursk 90 x (Er14/83xHabar) & 85 & 90 & 80 & 8 & 7 & 6 \\
\hline 9. 303-82 x (Am1495 x Lyt 937) & 80 & 90 & 70 & 7 & 9 & 7 \\
\hline 11. Amurskaya 1495 x Buryatsk 94 & 85 & 95 & 90 & 7 & 8 & 6 \\
\hline 12. Aryuna x Amurskaya 1495 & 80 & 80 & 90 & 7 & 6 & 6 \\
\hline 13. Aryuna x Zaryanka & 75 & 80 & 85 & 9 & 9 & 7 \\
\hline 17. DalGAU 1 x Lada & 85 & 95 & 100 & 9 & 9 & 6 \\
\hline 18. Pushkinskaya x Katyusha & 80 & 80 & 90 & 8 & 8 & 7 \\
\hline 22. Amurskaya 1495 x Lada & 80 & 85 & 90 & 8 & 9 & 6 \\
\hline 23. Amurskaya 1495 x Jo08429 & 75 & 80 & 80 & 8 & 8 & 5 \\
\hline 24. DalGAU 1 x Planett & 70 & 80 & 85 & 9 & 9 & 9 \\
\hline 25. DalGAU 2 x Prizeyskaya & 80 & 90 & 90 & 7 & 8 & 5 \\
\hline 27. Aryuna x Kadett & 90 & 100 & 85 & 7 & 9 & 6 \\
\hline 32. Amurskaya 1495 x Jo 08429 & 80 & 80 & 85 & 9 & 8 & 8 \\
\hline 33. BSHI 1 x Fan 8 & 85 & 100 & 90 & 7 & 9 & 7 \\
\hline 34. Aryuna x Zunnan & 75 & 95 & 90 & 7 & 9 & 7 \\
\hline 36. Amurskaya 1495 x Omskaya & 70 & 95 & 90 & 8 & 5 & 6 \\
\hline 37. P-2-05 x Aryuna & 85 & 100 & 90 & 8 & 9 & 7 \\
\hline 38. DalGAU 1 x Lada & 75 & 90 & 90 & 8 & 8 & 6 \\
\hline 39. Amurskaya 1495 x DalGAU 1 & 75 & 90 & 100 & 8 & 6 & 6 \\
\hline
\end{tabular}

Of all mentioned, samples KSI-13 (Aryuna x Zaryanka) and KSI-32 (Amurskaya 1495 $\mathrm{x}$ Jo 08429) should be noted particularly, as over three years of study, they had lodging resistance up to 8 points; as well as KSI-24 (DalGAU 1 x Planett), which in all weather conditions has had the highest stability of 9 points. All three of these varieties had culm lengths not longer than $85 \mathrm{~cm}$, that is, according to European standards, they are shortstemmed. The remaining varieties can be attributed to medium height plants.

Obtaining high-quality food grain in Amur region is directly dependent on the degree of damage to plants and grains by fungal diseases, rapidly developing with high humidity and soil overwetting [5-7]. The main harmful diseases that significantly reduce the technological and sowing qualities of grain are dust-brand, grain fusariose, and some 
diseases of Helminthosporiosis and Alternaria called the "kernel black point of grain". The most widespread development of dust-brand was noted in 2017 when it was found in 10 of 21 samples. In the next two years, single affected samples were found (Table 3).

Unlike dust-brand, which in some years may manifest itself insignificantly or even be absent, the kernel black point of grain and fusariose are regularly observed in all varieties to a certain degree $[8,9]$. The more there is precipitation, the fewer resistance varieties show to these diseases with more grains being affected and worse sowing and technological properties. Cultivation of highly resistant varieties of spring wheat is the most important task for the local specialists.

The lowest resistance of varieties to grain fusariose and glume mold was recorded in 2019, which happened to be the dampest and unfavorable for grain growing year. The resistance ability of the number of samples decreased to critical 4-5 points. In 12 variety specimens, the resistance never went down lower 6 points during three years of studies. KSI-18 (Pushkinskaya x Katyusha) sample stood out among them during three years of study with high resistance to both diseases (7-8 points).

Table 3. Resistance to fungal diseases.

\begin{tabular}{|l|c|c|c|c|c|c|}
\hline \multirow{2}{*}{ Variety } & \multicolumn{3}{|c|}{ Kernel smut affection, \% } & \multicolumn{3}{|c|}{$\begin{array}{c}\text { Resistance to grain fusariose / } \\
\text { glume mould, points }\end{array}$} \\
\cline { 2 - 7 } & 2017 & 2018 & 2019 & 2017 & 2018 & 2019 \\
\hline 3. DalGAU 1 standard & 0.04 & 0 & 0 & $7 / 6$ & $6 / 7$ & $5 / 7$ \\
\hline 6. DalGAU 1 x Turinskaya & 0.04 & 0 & 0 & $7 / 6$ & $5 / 6$ & $6 / 8$ \\
\hline 7. Amursk 90 x (Er14/83xHabar) & 0.08 & 0 & 0 & $7 / 6$ & $5 / 6$ & $4 / 7$ \\
\hline 9. 303-82 x (Am1495 x Lyt 937) & 0 & 0 & 0 & $6 / 6$ & $7 / 6$ & $5 / 7$ \\
\hline 11. Amurskaya 1495 x Buryatsk 94 & 0.1 & 0 & 0 & $6 / 5$ & $6 / 6$ & $5 / 7$ \\
\hline 12. Aryuna x Amurskaya 1495 & 0 & 0 & 0 & $7 / 7$ & $6 / 7$ & $6 / 6$ \\
\hline 13. Aryuna x Zaryanka & 0 & 0 & 0 & $7 / 7$ & $6 / 6$ & $6 / 7$ \\
\hline 17. DalGAU 1 x Lada & 0.02 & 0 & 0.02 & $6 / 6$ & $6 / 6$ & $7 / 7$ \\
\hline 18. Pushkinskaya x Katyusha & 0 & 0 & 0 & $7 / 7$ & $8 / 7$ & $7 / 8$ \\
\hline 22. Amurskaya 1495 x Lada & 0.02 & 0 & 0.02 & $7 / 5$ & $7 / 7$ & $7 / 7$ \\
\hline 23. Amurskaya 1495 x Jo08429 & 0.04 & 0 & 0 & 7,7 & $6 / 6$ & $6 / 7$ \\
\hline 24. DalGAU 1 x Planett & 0 & 0 & 0.2 & $6 / 5$ & $7 / 7$ & $6 / 6$ \\
\hline 25. DalGAU 2 x Prizeyskaya & 0 & 0 & 0 & $6 / 6$ & $7 / 7$ & $7 / 8$ \\
\hline 27. Aryuna x Kadett & 0.04 & 0 & 0 & $6 / 4$ & $7 / 6$ & $6 / 7$ \\
\hline 32. Amurskaya 1495 x Jo 08429 & 0.14 & 0.04 & 0 & $6 / 6$ & $7 / 7$ & $7 / 7$ \\
\hline 33. BSHI 1 x Fan 8 & 0 & 0 & 0 & $6 / 6$ & $7 / 6$ & $7 / 7$ \\
\hline 34. Aryuna x Zunnan & 0 & 0 & 0 & $7 / 6$ & $7 / 6$ & $7 / 7$ \\
\hline 36. Amurskaya 1495 x Omskaya & 0 & 0 & 0 & $6 / 6$ & $6 / 6$ & $5 / 7$ \\
\hline 37. P-2-05 x Aryuna & 0 & 0 & 0 & $7 / 7$ & $7 / 6$ & $5 / 6$ \\
\hline 38. DalGAU 1 x Lada & 0.1 & 0 & 0 & $6 / 6$ & $6 / 6$ & $6 / 7$ \\
\hline 39. Amurskaya 1495 x DalGAU 1 & 0 & 0 & 0 & $7 / 7$ & $6 / 6$ & $6 / 7$ \\
\hline
\end{tabular}

Crop capacity is a decisive indicator of a variety's value for production [10]. The local variety DalGAU 1, zoned in the Far East, was used as a standard. The vegetation period of Amur varieties is quite stable and ranges from 85 to 92 days. It was the longest in 2018 when the grain of most samples ripened in 91 days. The maximum yield was harvested in 2017, which was relatively dry, compared to the following two years. The varieties yielded up to $4.73 \mathrm{t}$ /ha (ton per hector, metric) - KSI-13, Aryuna x Zaryanka (Table 4). Two other varieties brought bigger yields compared to the standard: KSI-7 (Amursk 90 x (Er14 / 83 x Khabar) made up $4.63 \mathrm{t} / \mathrm{ha}$ and KSI-39 (Amurskaya $1495 \times$ DalGAU 1) - $4.62 \mathrm{t} / \mathrm{ha}$. Higher than that of DalGAU 1 productivity for two years out of three was shown by KSI-6 (DalGAU 1 x Turinskaya), KSI-13 (Aryuna x Zaryanka), KSI-17 (DalGAU x Lada), KSI- 
39 (Amurskaya 1495 x DalGAU 1) varieties. Also, the KSI-18 (Pushkinskaya x Katyusha) variety among all samples deserves a special note for the maximum yield with minimal damage from fungoid infections during wet summer year.

Table 4. Vegetation period and yields.

\begin{tabular}{|l|c|c|c|c|c|c|}
\hline \multirow{2}{*}{ Variety } & \multicolumn{3}{|c|}{ Vegetation period, days } & \multicolumn{3}{c|}{ Yield, tons per hector $(\mathrm{t} / \mathrm{h})$} \\
\cline { 2 - 7 } & 2017 & 2018 & 2019 & 2017 & 2018 & 2019 \\
\hline 3. DalGAU 1 standard & 85 & 91 & 86 & 4.61 & 3.13 & 2.95 \\
\hline 6. DalGAU 1 x Turinskaya & 85 & 91 & 89 & 4.19 & 3.61 & 3.53 \\
\hline 7. Amursk 90 x (Er14/83xHabar) & 85 & 91 & 87 & 4.63 & 3.12 & 2.96 \\
\hline 9. 303-82 x (Am1495 x Lyt 937) & 86 & 91 & 88 & 4.11 & 2.97 & 3.06 \\
\hline 11. Amurskaya 1495 x Buryatsk 94 & 87 & 93 & 86 & 3.84 & 2.99 & 3.37 \\
\hline 12. Aryuna x Amurskaya 1495 & 85 & 89 & 86 & 4.45 & 2.86 & 2.74 \\
\hline 13. Aryuna x Zaryanka & 88 & 90 & 88 & 4.73 & 3.20 & 3.30 \\
\hline 17. DalGAU 1 x Lada & 85 & 91 & 88 & 4.03 & 3.45 & 3.50 \\
\hline 18. Pushkinskaya x Katyusha & 88 & 92 & 87 & 3.59 & 2.15 & 4.00 \\
\hline 22. Amurskaya 1495 x Lada & 86 & 91 & 85 & 4.10 & 3.02 & 3.04 \\
\hline 23. Amurskaya 1495 x Jo08429 & 88 & 91 & 85 & 3.90 & 2.97 & 2.98 \\
\hline 24. DalGAU 1 x Planett & 89 & 91 & 85 & 4.23 & 3.13 & 3.10 \\
\hline 25. DalGAU 2 x Prizeyskaya & 88 & 89 & 86 & 4.18 & 2.67 & 2.98 \\
\hline 27. Aryuna x Kadett & 86 & 91 & 88 & 4.22 & 3.19 & 3.23 \\
\hline 32. Amurskaya 1495 x Jo 08429 & 86 & 91 & 86 & 4.31 & 2.44 & 3.34 \\
\hline 33. BSHI 1 x Fan 8 & 87 & 91 & 88 & 4.33 & 2.93 & 2.73 \\
\hline 34. Aryuna x Zunnan & 88 & 91 & 88 & 4.35 & 3.08 & 3.05 \\
\hline 36. Amurskaya 1495 x Omskaya & 85 & 91 & 86 & 4.23 & 3.06 & 2.82 \\
\hline 37. P-2-05 x Aryuna & 87 & 91 & 89 & 4.07 & 3.36 & 2.52 \\
\hline 38. DalGAU 1 x Lada & 86 & 91 & 85 & 4.08 & 3.45 & 3.09 \\
\hline 39. Amurskaya 1495 x DalGAU 1 & 86 & 91 & 86 & 4.62 & 3.10 & 3.13 \\
\hline HCP 05 & - & - & - & 0.43 & 0.37 & 0.30 \\
\hline
\end{tabular}

The quality of produced wheat grain is becoming increasingly important. It depends on many factors and determines how a certain yield will be used further. An important guideline for assessing product quality is the natural weight index. The most favorable for the formation of high natural weight was 2017 when seven varieties could be attributed to the valuable wheat varieties and 5 - to the strong ones. During the next two unfavorable precipitation excessive years only 4 varieties in 2018 and 6 ones in 2019 could be classified as valuable and strong (Table 5).

Among all studied samples, KSI-6 (DalGAU 1 x Turinskaya), KSI-18 (Pushkinskaya x Katyusha), KSI-25 (DalGAU 2 x Prizeiskaya), KSI-32 (Amurskaya 1495 x Jo 08429), KSI38 (DalGAU 1 x Lada) should be distinguished, as during two years out of three they all generated the grain whose characteristics corresponded to the strong and valuable level. At that KSI-22 (Amurskaya 1495 x Lada) variety needs to be mentioned separately, as its natural weight corresponded to the strong or valuable class under any weather conditions.

Grain vitreousness, like natural weight, is highly dependent on the weather conditions during the vegetation period [11,12]. In the most favorable, the high-yield year 2017, with the largest natural weight and thousand-seed weight, grain vitreousness was the lowest. In some varieties, it was only $18-34 \%$. Most varieties, up to $56 \%$ to be exact, belonged to valuable wheat for their vitreousness. The strongest vitreousness was identified in 2018 . According to this feature, seventeen varieties can be classified as strong wheat, four varieties as valuable ones. In 2019, eleven varieties could be classified as strong, ten varieties as valuable ones. For the entire study period, fifteen varieties annually remained in the class of strong or valuable. 
The thousand-seed weight represents the grain size and is an important quality characteristic. Almost all varieties in 2017 can be attributed to the group of varieties with a big seed size of over $30 \mathrm{~g}$ (grams, metric). The maximum value of this trait was noted in KSI-18 (Pushkinskaya x Katyusha) variety (42.6 g) and KSI-22 (Amurskaya 1495 x Lada) variety (37.1 g). In 2018 and 2019, the thousand-seed weight index was lower and generally corresponded to the group of medium-weight grains with 25 to $30 \mathrm{~g}$ seeds.

For two years, the largest grains were owned by KSI-6 (DalGAU 1 x Turinskaya), KSI17 (DalGAU 1 x Lada), KSI-18 (Pushkinskaya x Katyusha) varieties. Throughout the entire study time, large grains were formed by KSI-11 (Amurskaya 1495 x Buryatsk 94), KSI-22 (Amurskaya 1495 x Lada), KSI-33 (BSHI 1 x Fan 8) varieties.

Table 5. Natural Weight, Vitreousness, Thousand-Seed Weight of varieties under study.

\begin{tabular}{|c|c|c|c|c|c|c|c|c|c|}
\hline \multirow[t]{2}{*}{ Variety } & \multicolumn{3}{|c|}{$\begin{array}{c}\text { Natural } \\
\text { Weight, g/l } \\
\text { (grams per } \\
\text { liter, metric) } \\
\end{array}$} & \multicolumn{3}{|c|}{$\begin{array}{c}\text { Vitreousness, } \\
\%\end{array}$} & \multicolumn{3}{|c|}{$\begin{array}{l}\text { Thousand-Seed } \\
\text { Weight, g } \\
\text { (grams, metric) }\end{array}$} \\
\hline & 궁 & $\stackrel{\infty}{\stackrel{\sim}{*}}$ & 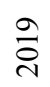 & 홍 & $\stackrel{\infty}{\stackrel{\sim}{*}}$ & $\stackrel{\vec{\partial}}{\partial}$ & 홍 & $\stackrel{\infty}{\stackrel{2}{*}}$ & ळे \\
\hline 3.DalGAU 1 standard & $\hat{n}$ & $\stackrel{8}{2}$ & $\mathscr{\infty}$ & nี & 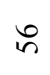 & 6 & $\stackrel{\circ}{m}$ & $\begin{array}{l}\dot{0} \\
\ddot{d}\end{array}$ & $\underset{\sim}{\sim}$ \\
\hline 6.DalGAU 1 x Turinskaya & ํㅏㅁ & \&̊ & $\stackrel{8}{2}$ & 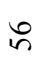 & $\bar{\infty}$ & 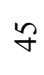 & $\dot{m}$ & $\stackrel{\text { ণे }}{\circ}$ & $\stackrel{0}{\grave{\lambda}}$ \\
\hline 7.Amursk 90 x (Er14/83xHabar) & $\stackrel{n}{\pi}$ & శి & $\frac{n}{6}$ & $\stackrel{\infty}{-}$ & $\stackrel{2}{r}$ & $\stackrel{\circ}{n}$ & $\frac{n}{m}$ & $\stackrel{\infty}{\sim}$ & 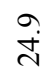 \\
\hline 9.303-82 x (Am1495 x Lyt 937) & ํ & \& & $\stackrel{?}{2}$ & $\approx$ & $\stackrel{n}{n}$ & 우 & ते. & 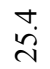 & \\
\hline 11. Amurskaya 1495 x Buryatsk 94 & 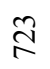 & \& & \& & $\ddot{m}$ & $\stackrel{\infty}{\curvearrowright}$ & in & $\overrightarrow{i n}$ & $\underset{\sim}{\stackrel{\sim}{*}}$ & aे \\
\hline 12. Aryuna x Amurskaya 1495 & $\stackrel{\circ}{i}$ & $\ddot{\infty}$ & \& & $\stackrel{\vartheta}{q}$ & $\infty$ & in & $\overrightarrow{0}$ & $\stackrel{\vec{v}}{\ddot{\sim}}$ & $\begin{array}{l}\stackrel{n}{\sim} \\
\text { an }\end{array}$ \\
\hline 13. Aryuna x Zaryanka & 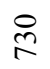 & $\frac{n}{6}$ & $\stackrel{ }{ }$ & 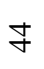 & $\infty$ & 운 & $\begin{array}{l}\text { o } \\
\text { mi }\end{array}$ & $\begin{array}{l}0 \\
\ddot{\sim}\end{array}$ & $\stackrel{n}{\sim}$ \\
\hline 17. DalGAU 1 x Lada & হ & 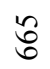 & $\stackrel{n}{r}$ & ले & 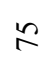 & t & in & $\begin{array}{l}\dot{\sim} \\
\ddot{\sim}\end{array}$ & $\underset{j}{\dot{0}}$ \\
\hline 18. Pushkinskaya x Katyusha & 孚 & 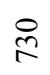 & 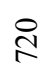 & 요 & H & 2 & $\begin{array}{l}\underset{j}{f} \\
\stackrel{f}{f}\end{array}$ & $\underset{\nabla}{\dot{v}}$ & 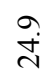 \\
\hline 22. Amurskaya 1495 x Lada & t? & 옴 & 용 & 于 & $\stackrel{\infty}{\curvearrowright}$ & $\exists$ & $\vec{m}$ & $\begin{array}{l}0 \\
\infty \\
\sim \\
\sim\end{array}$ & $\overrightarrow{\text { वे }}$ \\
\hline 23. Amurskaya 1495 x Jo08429 & $\underset{尺}{\stackrel{D}{2}}$ & \& & 으 & 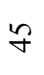 & in & $n$ & $\begin{array}{l}\text { o } \\
\text { mi }\end{array}$ & $\stackrel{+}{\stackrel{+}{d}}$ & $\begin{array}{l}0 \\
\dot{\sim}\end{array}$ \\
\hline 24. DalGAU $1 \times$ Planett & $\stackrel{\circ}{N}$ & 웅 & $\stackrel{\cap}{n}$ & $\tilde{m}$ & ஃ & 2 & थे & $\stackrel{\circ}{\sim}$ & $\ddot{n}$ \\
\hline 25.DalGAU 2 x Prizeyskaya & iे & 8 & $\stackrel{n}{n}$ & g & $\Re$ & $\widehat{6}$ & $\underset{m}{\dot{m}}$ & $\begin{array}{l}\text { ते } \\
\text { ते }\end{array}$ & n? \\
\hline
\end{tabular}




\begin{tabular}{|c|c|c|c|c|c|c|c|c|c|}
\hline \multirow[t]{2}{*}{ Variety } & \multicolumn{3}{|c|}{$\begin{array}{c}\text { Natural } \\
\text { Weight, g/l } \\
\text { (grams per } \\
\text { liter, metric) } \\
\end{array}$} & \multicolumn{3}{|c|}{$\begin{array}{c}\text { Vitreousness, } \\
\%\end{array}$} & \multicolumn{3}{|c|}{$\begin{array}{l}\text { Thousand-Seed } \\
\text { Weight, g } \\
\text { (grams, metric) }\end{array}$} \\
\hline & 홍 & $\stackrel{\infty}{\stackrel{i}{*}}$ & $\frac{a}{\circ}$ & 홍 & $\stackrel{\infty}{\stackrel{\sim}{\sigma}}$ & $\frac{a}{\stackrel{i}{े}}$ & 홍 & $\stackrel{\infty}{\stackrel{\sim}{\sigma}}$ & $\frac{\text { aे }}{2}$ \\
\hline 27. Aryuna x Kadett & $\stackrel{\infty}{N}$ & $\stackrel{\infty}{\infty}$ & $\stackrel{0}{1}$ & 导 & F & in & $\underset{n}{n}$ & $\stackrel{+}{\stackrel{\sim}{~}}$ & $\stackrel{\nabla}{\sim}$ \\
\hline 32. Amurskaya 1495 x Jo 08429 & $\underset{r}{2}$ & $\stackrel{0}{1}$ & $\approx$ & $\tilde{n}$ & $\infty$ & 8 & $\stackrel{n}{m}$ & $\begin{array}{l}\infty \\
\ddot{d}\end{array}$ & $\stackrel{?}{0}$ \\
\hline 33. BSHI $1 \times$ Fan 8 & $\underset{⿱}{*}$ & 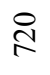 & $\frac{n}{n}$ & $\stackrel{+}{+}$ & $\stackrel{2}{r}$ & $\exists$ & $m$ & $\begin{array}{l}0 \\
\infty \\
\stackrel{\sim}{\sim}\end{array}$ & $\begin{array}{l}0 \\
\stackrel{0}{0}\end{array}$ \\
\hline 34. Aryuna x Zunnan & $\stackrel{\infty}{\infty}$ & 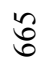 & $\stackrel{2}{\pi}$ & gे & 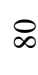 & ஜ & $\begin{array}{l}\dot{0} \\
\text { in }\end{array}$ & 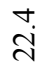 & 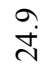 \\
\hline 36. Amurskaya 1495 x Omskaya & 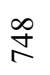 & $\stackrel{\circ}{ }$ & వి & \& & $\stackrel{2}{2}$ & $n$ & $\frac{m}{m}$ & $\begin{array}{l}\ddot{n} \\
\ddot{n}\end{array}$ & $\stackrel{\sim}{\stackrel{\sim}{\sim}}$ \\
\hline 37. P-2-05 x Aryuna & $\hat{\sim}$ & $\stackrel{n}{*}$ & $\tilde{8}$ & \& & $\tilde{6}$ & ช & $\stackrel{n}{i}$ & $\stackrel{\circ}{\circ}$ & $\stackrel{\sim}{\infty}$ \\
\hline 38. DalGAU 1 x Lada & $\overrightarrow{8}$ & 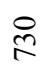 & $\mathfrak{\sigma}$ & ร & $\cong$ & $\approx$ & $\stackrel{n}{m}$ & ஜें & $\stackrel{\sim}{\dot{d}}$ \\
\hline 39. Amurskaya 1495 x DalGAU 1 & 齐 & \&̊+ & $\frac{n}{\pi}$ & $\vartheta$ & $\bar{\sigma}$ & $\widehat{6}$ & $\frac{\dot{A}}{m}$ & $\begin{array}{l}\ddot{i} \\
\ddot{\sim}\end{array}$ & $\stackrel{\stackrel{\sim}{d}}{ }$ \\
\hline
\end{tabular}

\section{Conclusion}

Therefore, the study of new varieties in crop nurseries has made it possible to identify a number of samples possessing valuable traits that can be proceeded for the federal variety testing.

Based on three-year observations, it should be noted that most of the studied selection samples are medium height, resistant to lodging, successfully withstanding significant overwetting of the soil. Against the background of natural infection, a number of varieties are resistant to such dangerous, widespread infections as dust-brand, grain fusariose, and glume mould.

Varieties with a yield higher than the standard were identified and that by grain quality can be classified as valuable and strong wheat. As a result of the obtained data analysis, four promising spring wheat varieties can be distinguished as candidates for the federal variety testing.

KSI-13 variety was cultivated by crossing Aryun (Buryatia) and Zaryanka (Khabarovsky region) varieties. The outcome is the short-stemmed, resistant to lodging and fungal diseases crop, with the vegetation period of 88-90 days. In 2018 and 2019, it's yield was significantly higher compared to the standard volumes.

KSI-18 variety was cultivated by crossing Pushkinskaya (Amur region) and Katyusha (Omsk region) varieties. It is short-stemmed, resistant to logging, highly resistant to fungal diseases against the natural infectious background, with 88-92 days vegetation period. In the unfavorable weather conditions of 2019, with heavy rainfall and waterlogging of the soil, the variety showed the best yields of all tested ones. It can be classified as valuable and 
strong wheat by natural weight and vitreousness and can generate large seeds of over $40 \mathrm{~g}$ by the thousand-seed weight index.

KSI-6 variety was obtained by intraspecific hybridization of DalGAU 1 (Amur region) with Turinskaya 6 (Sverdlovsk) varieties. The variety's stem is medium-high, about 75 to $95 \mathrm{~cm}$ (centimeters, metric), with an average resistance to lodging and fungal disease damage. Its vegetation period is 85-91 days. During two years out of three, it was significantly more productive than the standard. It has large grains and can be attributed to strong and valuable varieties by its quality.

KSI-17 variety was cultivated by crossing DalGAU 1 (Amur region) with Lada (Ulyanovsk). The variety's stem is medium-high, about $85-100 \mathrm{~cm}$, quite resistant to lodging, with medium resistance to fungal infections and vegetation period of 85-91 days. During two years out of three, it was more productive than the standard. It has large grain and in some years can be attributed to valuable varieties by natural weight and vitreousness.

\section{References}

1. I.F.Demina, S.V. Kosenko Assessment results of spring soft wheat starting material for lodging resistance, Bulletin of Altay State Agrarian University 8 (130), (2015)

2. G.S. Balyk, Types of nodal roots in selection for plant resistance to lodging, Selection and Seed Production 4 P. 4-8 (1982)

3. G V Gulyaev G.V., Yu L Guzhov Yu.L., Selection and seed production of field crops , $447 \mathrm{p}$ (1987)

4. A. A. Zhuchenko Resource potential of grain production in Russia (2004)

5. A. V. Kharina Adaptive potential of dust-brand resistant spring soft wheat varieties, Agrarian Science of Euro-North-East, 3 (46), 28-31 (2015)

6. V. I. Krivchenko The study of the stability of crops and the racial composition of brand spore pathogens, 107 (1987)

7. E. D. Nettevich, A. I. Morgunov, M. I. Maksimenko Improving the efficiency of spring wheat selection on the stability of yield and grain quality, Bulletin of Agricultural Science, 1, 66-73 (1985)

8. M. M. Kovalenko, The resistance of soft wheat to spike fusariose// Genetic resources of cultivated plants in the twenty-first century, 81-82 (2007)

9. I. B. Ablova, Principles and methods for selecting disease-resistant wheat varieties (by the example of spike fusariose), and their role in the formation of agro-ecosystems: 49 p (2008)

10. L. V. Volkova, Spring soft wheat crop capacity and its connection with productivity elements in meteorologically different years Agrarian Science of Euro-North-East, 6 (55), 9-15 (2016)

11. A. I. Kuzmenko, Spring soft wheat varieties from the city of Saratov (Practical Selection). Saratov: Printhouse of Saratov University, 300 (2005)

12. M. J. Guttieri, J. C. Stark Relative sensitivity of spring wheat grain yield and quality parameters to moisture deficit Crop Sci V. 41, 327-335 (2001) 